\title{
Occurrence of the Yellow-spotted Wolf Snake (Lycodon flavomaculatus Wall 1907) in Surat, Gujarat, India
}

Krunal Trivedi ${ }^{1}$ and Vyom Shah ${ }^{2}$

${ }^{1}$ A-26, Kasturba Mahila Society, Palanpur Patiya, Surat (Gujarat), 395009, India (lovetoliveinwild@gmail.com)

${ }^{2}$ B-504, Kedardham Appartment, New Rander road, Surat (Gujarat), 395009, India (vyom_shah23@yahoo.in)

$\mathrm{O}$ n 11 June 2017, we encountered a Yellow-spotted Wolf Snake (Lycodon flavomaculatus Wall, 1907) in Mindhi Village, Surat, Gujarat, India $\left(21^{\circ} 22^{\prime} 52.90^{\prime \prime N}\right.$, $\left.72^{\circ} 42^{\prime} 27.11 " \mathrm{E}\right)$. The snake was moving along a field margin next to a fallow field at $2115 \mathrm{~h}$. Rocks, low vegetation, and fallen logs were in the surrounding area. The snake was docile and non-offensive while scale counts and photographs were taken. Scale counts confirmed it as a Yellow-spotted Wolf Snake (these snakes resemble the Barred Wolf Snake, L. striatus, but are readily distinguished using meristic characters). We found another snake at $2030 \mathrm{~h}$ on 15 April 2015 in a human settlement in the Olpad region of Surat, Gujarat $\left(21^{\circ} 19^{\prime} 44.89^{\prime \prime} \mathrm{N}, 72^{\circ} 46^{\prime} 13.68^{\prime \prime} \mathrm{E}\right)$, where it was in a pile of bricks close to a house. It was rescued and released safely after data were collected. The distance between the two locations was about $8.73 \mathrm{~km}$. These are the first records of the species in the Surat District.

Found mainly in the semi-arid zone of central India and some parts of the Western Ghats, Yellow-spotted Wolf Snakes are nocturnal and, like other wolf snakes, quite secretive. Consequently, very little information is available about the species' distribution and natural history. These snakes

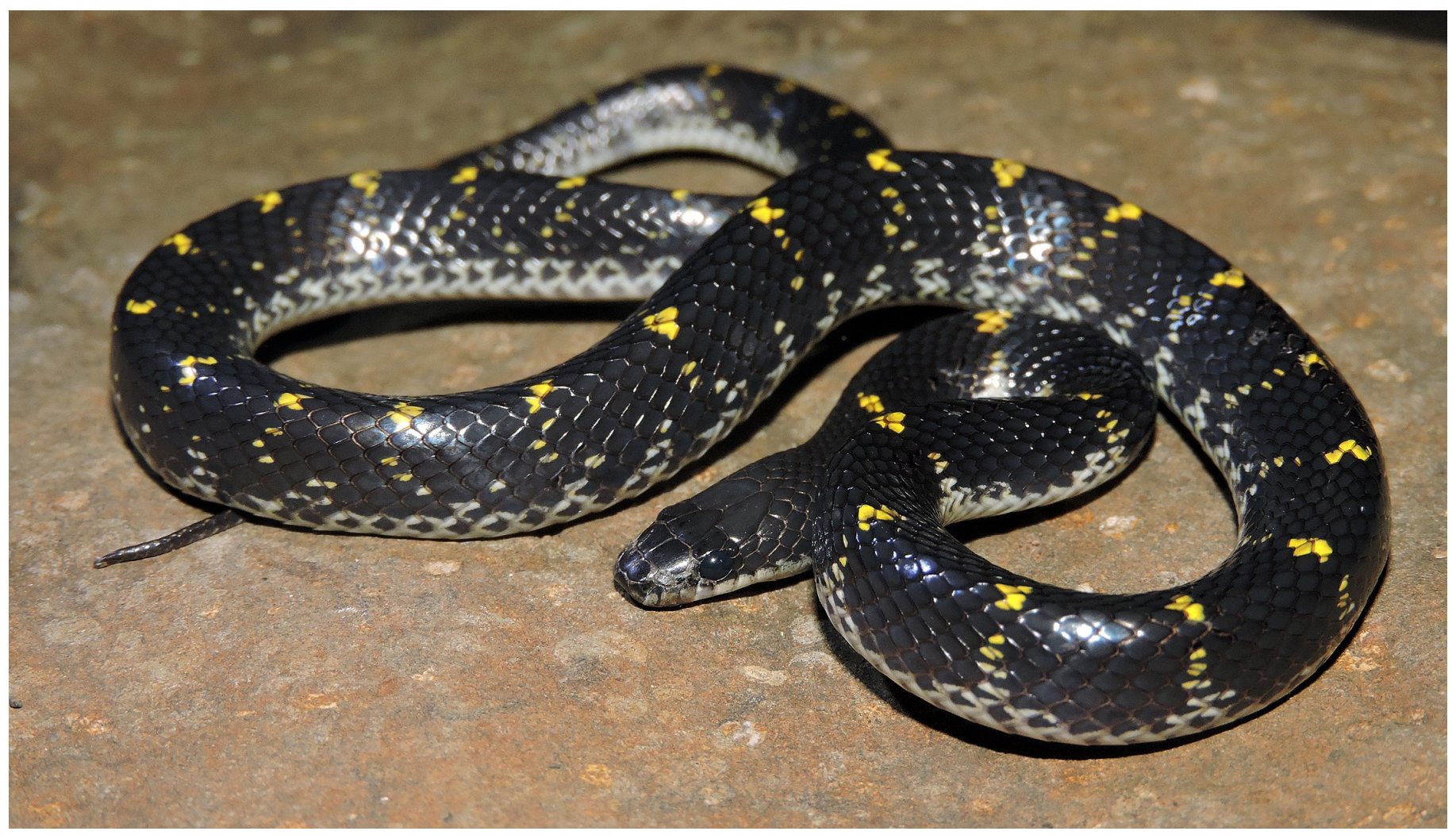

Fig. 1. A Yellow-spotted Wolf Snake (Lycodon flavomaculatus) from Mindhi, Surat, Gujarat, India. Photograph by Krunal Trivedi. 


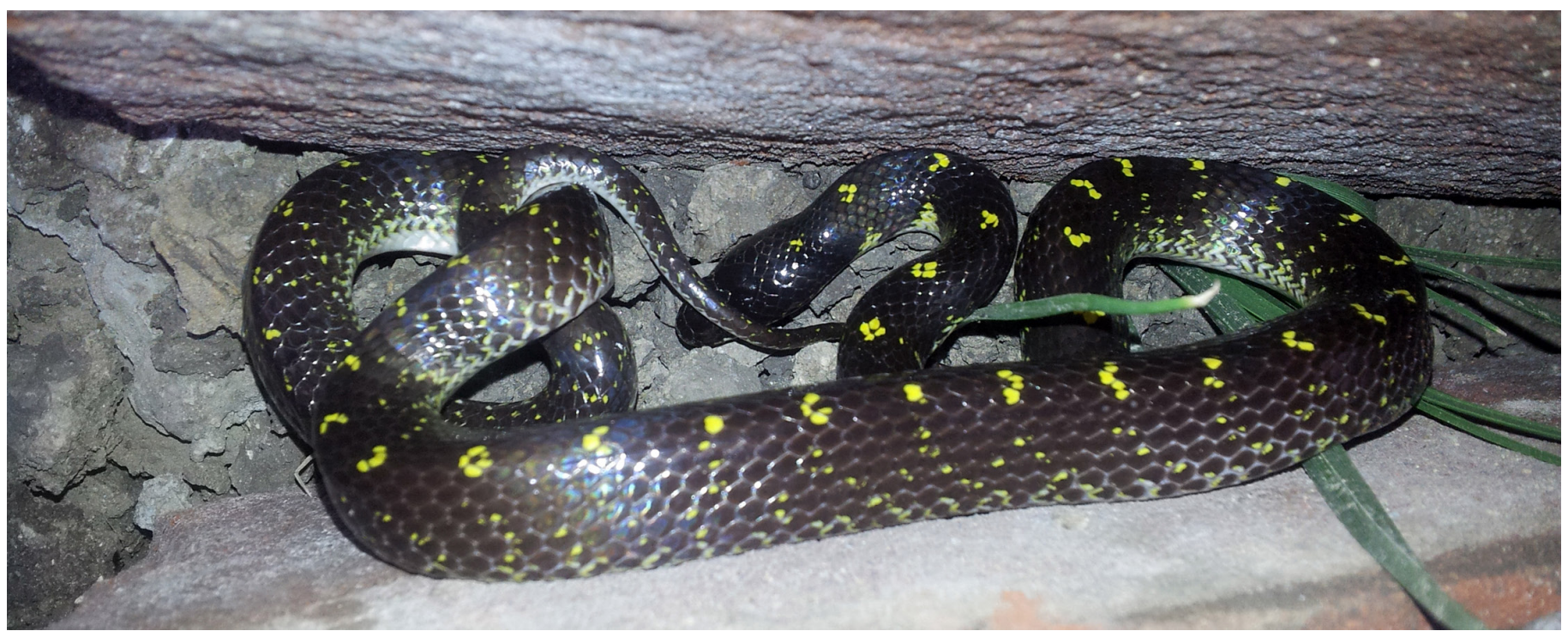

Fig. 2. A Yellow-spotted Wolf Snake (Lycodon flavomaculatus) rescued from a pile of bricks in Olpad, Surat, Gujarat, India. Photo by Vyom Shah.

are known to climb and feed on lizards and small rodents. The nearest known locality for this snake is from Vadodra (Vyas and Upadhyaya 2008). It also has been recorded from Vidisha, (Sharma et al. 2015), Madhya Pradesh, Dharwad in Karnataka (Wall 1907), Raigarh (Walmiki et al. 2011), Sangli, Pune, and Nashik (Wall 1907), Buldhana and Vidarbha (Wall 1923), Amravati, including Melghat (Pradhan 2005; Nande and Deshmukh 2007), Satara (Chikane and Bhosale 2012), Solapur (Srinivasulu et al. 2014), and Nagpur (Deshmukh et al. 2015) in Maharashtra, and Bhanvagar and Vadodara (Vyas and Upadhaya 2008) in Gujarat.

\section{Acknowledgements}

Our sincere thanks to Mr. Rajnikant Chauhan for helping us with data collection; Dr. Raju Vyas, Mr. Mehul Thakur, and Mr. Snehal Patel for motivation and support; and Vedant Lala and Jenish Patel for rescuing the snakes and assisting us with fieldwork.

\section{Literature Cited}

Sharma, V., A. Jain, and R. Bhandari. 2015. A new locality for the elusive and endemic Yellow-Spotted Wolf Snake (Lycodon flavomaculatus Wall 1907), with notes on distribution and habitat. Reptiles \& Amphibians 22: 164-167.
Boulenger, G.A. 1893. Catalogue of the Snakes in the British Museum (Natural History). Volume I., Containing the Families Typhlopida, Glauconiida, Boida, Ilysiida, Uropeltida, Xenopeltida, and Colubrida Aglypha, Part. Trustees of the British Museum (Natural History), London, UK.

Captain, A. 1999. On the identification of Lycodon flavomaculatus Wall 1907. Journal of the Bombay Natural History Society 96: 323-327.

Chikane, S. and H.S. Bhosale. 2012. Reptiles of Kaas, Northern Western Ghats, Maharashtra, India, with notes on habitat preferences, abundances and threats. Sauria 34(3): 3-15.

Deshmukh, R.V., S.A, Deshmukh, and S.A. Badekar. 2015. Rescued records of snakes from Nagpur District, Maharashtra with data on unrecorded species. Reptile Rap 17: 34-43.

Mukherjee, D. and S. Bhupathy. 2007. A new species of Wolf Snake (Serpentes: Colubridae: Lycodon) from Anaikatti Hills, Western Ghats, Tamil Nadu, India. Russian Journal of Herpetology 14: 21-26.

Murthy, T.S.N. 1991. A rare Wolf Snake, Lycodon flavomaculatus, from the Nilgiri Biosphere Reserve, South India. The Snake 23:104-106.

Pradhan, M.S. 2005. Reptilia. Fauna of Melghat Tiger Reserve. Conservation Area Series 24: 165-221.

Smith, M.A. 1943. The Fauna of British India, Ceylon and Burma, Including the Whole of the Indo-Chinese Sub-Region. Reptilia and Amphibia. Volume IIISerpentes. Taylor and Francis, London.

Vyas R. 2000. A review of reptile studies in Gujarat state. Zoos' Print Journal 15: 386-390.

Vyas, R. and K.B. Upadhaya. 2008. On the Occurrence of Lycodon flavomaculatus Wall, 1907 in Gujarat State, India. Sauria 30(1): 55-58.

Whitaker, R. and A. Captain. 2004. Snakes of India - The Field Guide. Draco Books, Chennai, India. 